\title{
HYDROLYSIS RATES OF DOMESTIC WASTEWATER SLUDGE USING BIOCHEMICAL METHANE POTENTIAL TESTS
}

\author{
U. A. Abubakar', M. A. Ajibike² and D. B. Adie ${ }^{3}$ \\ 1, 2, 3 Dept. of Water Resources and EnVIR. EnGR., Ahmadu Bello University Zaria, Kaduna State, NigERIA \\ E-mail addresses: ${ }^{1}$ uaabubakar@abu.edu.ng, ${ }^{2}$ maajibike@abu.edu.ng, ${ }^{3}$ dbadie@abu.edu.ng
}

\begin{abstract}
Domestic wastewater treatment can be improved by reducing energy consumption and increasing carbon recovery, which can be achieved using anaerobic digestion of sludge with methane recovery at ambient temperature. Hydrolysis can be a limiting step in anaerobic digestion, and characterisation of hydrolysis rates and process models should improve design and operation of treatment systems. The hydrolysis of primary sludge and secondary sludge were examined using biochemical methane potential (BMP) tests, with the monitoring of volatile solids concentrations and $p H$ values at $25^{\circ} \mathrm{C}$ and $37^{\circ} \mathrm{C}$, and data analysis using MATLAB non-linear least squares curve fitting to a first order hydrolysis model. Low reduction of solids was observed at $25^{\circ} \mathrm{C}$ compared to $37^{\circ} \mathrm{C}$, and higher hydrolysis rates at $25^{\circ} \mathrm{C}$ than at $37^{\circ} \mathrm{C}$. A correlation was observed between the first order model, digestion time and the reduction of solids based on coefficients of determination $\left(R^{2}\right)$. Model predictions were close to observed values, and therefore, the model should be reliable in predicting hydrolysis of sludge at $25^{\circ} \mathrm{C}$ and $37^{\circ} \mathrm{C}$.
\end{abstract}

Keywords: hydrolysis; domestic wastewater; sludge; biochemical methane.

\section{INTRODUCTION}

Sludge is the material collected through the sedimentation of particulate compounds during wastewater treatment, and its disposal is a critical aspect of domestic wastewater treatment [1]. Conventional wastewater treatment plants, for example activated sludge plants, usually produce two types of waste sludge, which are the primary sludge (PS) and the secondary sludge (SS) [2]. Primary sludge is collected in primary settling tanks in the treatment process, while secondary sludge is the particulate waste after aeration tanks or trickling filters, and is also referred to as waste activated sludge (WAS) for sludge from activated sludge plants. Several researchers have reported less than $50 \%$ of organic carbon recovery rates by systems treating domestic wastewater [3]. Anaerobic digestion of sludge from wastewater treatment plants can become a reliable method for carbon recovery in the form of methane [4], and there is a need to advance the understanding of the process in order to ensure efficiency.

Most anaerobic digesters are operated at a fixed mesophilic temperature in order to ensure process stability and efficiency, however recent concerns relating to energy efficiency and climate change has encouraged the consideration for digesters with low energy requirement or without temperature control [5]. A change in process temperature usually causes a change in the physical and chemical properties of wastewater [6 - 7], for example viscosity of liquids is influenced by temperature with high viscosity at low temperatures and therefore, different energy requirements for mixing will exist depending on process temperature [8]. Anaerobic digestion is a complex process which normally involves the following stages: hydrolysis (liquefaction), acidogenesis (acid formation), acetogenesis (acetate formation) and methanogenesis (methane formation) [9].

Hydrolysis is the conversion of the complex biodegradable organic matter into more readily soluble biodegradable matter which can then serve as necessary carbon source for the completion of the anaerobic process [10]. Hydrolysis is considered as a limiting step in anaerobic digestion, due to its slow rate and variations in characteristics of substrates, temperature and $\mathrm{pH}[10-11]$. The factors known to influence hydrolysis and anaerobic digestion include substrate characteristics, reactor configuration, operational parameters (for example hydraulic retention), the type of microorganisms present in the 
biomass, and environmental factors, such as temperature and $\mathrm{pH}$ value [10].

Generally, secondary sludge has reported hydrolysis rates half the rates reported for primary sludge and the performance of the anaerobic process will be influenced accordingly based on the nature of the substrate used as feedstock [12 - 13]. However, there is a wide range in the values of hydrolysis rates reported in literature, mainly due to different experimental conditions and biomass-to-substrate ratios [14]. The advancement of characterisation of hydrolysis rates and adoption process models based on the kinetics of anaerobic digestion can provide an understanding of hydrolysis behaviour and ensure accurate design and operation of anaerobic treatment of wastewater [15]. Most of the hydrolysis process models proposed in literature are considered to have a major limitation, which is they are usually based on specific experimental conditions, for example very high or very low substrates to microorganism ratio [16]. In a comparison of hydrolysis kinetic models, Vavilin et al. [17] concluded that their experimental data fits all the tested hydrolysis models comparatively well and therefore the application of first-order kinetics, which is the simplest way to describe the hydrolysis rate, is acceptable. Vavilin et al. [17] recommended the application of a first-order kinetic model to describe hydrolysis rates, where hydrolysis in a batch process can be represented in the form of Equation 1 [17].

$$
P=P_{o}\left(1-f_{h}\right)+f_{h} P_{o} e^{-k_{h} t}
$$

In (1), $P$ is the concentration of total substrate $(\mathrm{mg} / \mathrm{L})$, $\mathrm{P}_{\mathrm{o}}$ is the initial concentration of total substrate $(\mathrm{mg} / \mathrm{L})$, $f_{h}$ is the biodegradable fraction of substrate, $k_{h}$ is the hydrolysis rate constant $\left(\right.$ day $\left.^{-1}\right), t$ is the time (day) and $\mathrm{e}$ is the 2.7182

The aim of this paper is to evaluate the efficiency of the anaerobic hydrolysis of domestic wastewater primary sludge and secondary sludgeatambient temperature. Specific objectives of this paper are the evaluation of the influence of temperature on the efficiency of the hydrolysis process and the relationship of Equation 1 to the hydrolysis process. Consequently, the anaerobic digestion of domestic wastewater primary sludge and secondary sludge were monitored at $25^{\circ} \mathrm{C}$ and compared with digestion at $37^{\circ} \mathrm{C}$ using biochemical methane potential (BMP) batch tests.

\section{MATERIALS AND METHOD}

\subsection{Materials}

The substrates and anaerobic biomass used were:

a) A Five litre composite sample of domestic wastewater primary sludge; b) A Five litre composite sample of domestic wastewater secondary sludge;

c) A Five litre sample of anaerobic digested sludge;

The chemicals and reagents used were:

a) Ammonium Bicarbonate $\left(\mathrm{NH}_{4} \mathrm{HCO}_{3}\right)$, Sigma Aldrich, UK;

b) Potassium Dihydrogen Phosphate $\left(\mathrm{KH}_{2} \mathrm{PO}_{4}\right)$, Sigma Aldrich, UK;

c) Magnesium Sulphate $\left(\mathrm{MgSO}_{4}\right)$, Sigma Aldrich, UK;

d) Iron (III) Chloride $\left(\mathrm{FeCl}_{3}\right)$, Sigma Aldrich, $\mathrm{UK}_{\text {; }}$

e) Calcium Chloride $\left(\mathrm{CaCl}_{2}\right)$, Sigma Aldrich, UK;

f) Potassium Chloride (KCl), Sigma Aldrich, UK;

g) Cobalt (II) Chloride $\left(\mathrm{CoCl}_{2}\right)$, Sigma Aldrich, UK;

h) Nickel Chloride $\left(\mathrm{NiCl}_{2}\right)$, Sigma Aldrich, UK;

i) Sodium Bicarbonate $\left(\mathrm{NaHCO}_{3}\right)$, Sigma Aldrich, UK;

j) 10M Sodium Hydroxide $(\mathrm{NaOH})$ solution, Sigma Aldrich, UK;

k) Nitrogen gas (99\%), Sigma Aldrich, UK;

The major instruments used were:

a) SenSION3 $\mathrm{pH}$ probe and meter (Hach Company, Loveland Colorado U.S.A)

b) DR 5000 Hach Lange spectrophotometer (Hach Lange, Salford Manchester, UK)

c) MATLAB curve fitting toolkit (MATLAB R2013a student version, MathWorks, Cambridge, UK)

d) $500 \mathrm{~mL}$ glass bottles (Fisher Scientific, UK)

e) $25^{\circ} \mathrm{C}$ cabinet incubator

f) $37^{\circ} \mathrm{C}$ cabinet incubator

g) $105^{\circ} \mathrm{C}$ oven

h) $550^{\circ} \mathrm{C}$ furnace

\subsection{Preparation of the BMP Batch Tests}

The five litre composite samples of the primary sludge and secondary sludge were obtained from various domestic wastewater treatment plants in Scotland, through the agency responsible for sewerage services in Scotland, Scottish Water. Digested sludge was sourced from the anaerobic digester of Hatton wastewater treatment plant in Arbroath, Scotland, and used as a source for anaerobic biomass. A nutrient solution was also prepared, as recommended by Angelidaki and Sanders [18], containing only micronutrients and trace metals necessary for growth of microorganisms dissolved in distilled water without any substantial amount of organic carbon [18]. The composition of the nutrient medium in this study was: $75 \mathrm{mg} / \mathrm{L}$ Ammonium Bicarbonate $\left(\mathrm{NH}_{4} \mathrm{HCO}_{3}\right), 400$ $\mathrm{mg} / \mathrm{L}$ Potassium Dihydrogen Phosphate $\left(\mathrm{KH}_{2} \mathrm{PO}_{4}\right), 5.0$ $\mathrm{mg} / \mathrm{L}$ Magnesium Sulphate $\left(\mathrm{MgSO}_{4}\right), 5.0 \mathrm{mg} / \mathrm{L}$ Iron (III) Chloride $\left(\mathrm{FeCl}_{3}\right), 5.0 \mathrm{mg} / \mathrm{L}$ Calcium Chloride $\left(\mathrm{CaCl}_{2}\right)$, 
$5.0 \mathrm{mg} / \mathrm{L}$ Potassium Chloride (KCl), $1.0 \mathrm{mg} / \mathrm{L}$ Cobalt (II) Chloride $\left(\mathrm{CoCl}_{2}\right), 1.0 \mathrm{mg} / \mathrm{L}$ Nickel Chloride $\left(\mathrm{NiCl}_{2}\right)$ and $500 \mathrm{mg} / \mathrm{L}$ Sodium Bicarbonate $\left(\mathrm{NaHCO}_{3}\right)$.

The substrates and anaerobic biomass were characterized to determine their initial total solids (TS), volatile solids (VS), $\mathrm{pH}$ and volatile fatty acids (VFA) concentrations prior to initiation of the BMP tests. The anaerobic biomass was degassed for 48 hours by incubating at $37^{\circ} \mathrm{C}$ before the preparation of the BMP tests. $500 \mathrm{~mL}$ glass bottles sealed with thick rubber septum and aluminium caps were used for the tests, based on the recommended methodology by Angelidaki et al. [19], according to the compositions provided in Table 1, where each mixture was prepared in duplicate bottles and the experiment was carried out for 40 days.

The $\mathrm{pH}$ values of the final mixtures were adjusted by carefully adding a few drops of a $10 \mathrm{M}$ Sodium Hydroxide $(\mathrm{NaOH})$ solution to each mixture until the $\mathrm{pH}$ reading was between 7.51 and 7.88 . Then $350 \mathrm{~mL}$ of the mixtures were measured into labelled bottles, allowing for a headspace of $150 \mathrm{~mL}$ in order to avoid pressure build-up in the bottles once methane production started. The bottles were capped and the headspace was flushed with Nitrogen gas for 2 min to remove oxygen from the headspace, and then placed in $25^{\circ} \mathrm{C}$ and $37^{\circ} \mathrm{C}$ cabinet incubators.

\subsection{Collection of Samples from the BMP Tests}

Samples were collected from the BMP tests through the septum cap using Plastipak® $2 \mathrm{~mL}$ disposable plastic hypodermic syringes and 21-guage needles (Fisher Scientific, UK). For parameter analysis, samples were collected from each test condition in five $2 \mathrm{~mL}$ volumes and mixed to make $10 \mathrm{~mL}$ composite samples, in order not to deplete the volumes inside the test bottles before the experimental period elapsed.

\subsection{Analytical Method}

Total solids concentrations were determined based on recommended standard method [20], by drying the samples in an oven at $105^{\circ} \mathrm{C}$ over 24 hours, while the volatile solids concentrations were determined by igniting the dried samples in a furnace at $550^{\circ} \mathrm{C}$ for two hours. The measurements were performed in duplicate for each sample, and the average TS and VS was adopted. The $\mathrm{pH}$ of the samples was determined using a SenSION3 pH probe and meter (Hach Company, Loveland Colorado U.S.A). VFA concentrations, expressed as acetic acid (mg/L HOAC) within the range of $27-2800 \mathrm{mg} / \mathrm{L}$, were determined by spectrophotometry with the ferric hydroxamate method for determination of carboxylic esters [21 - 22], also known as the Montgomery method, using a DR 5000 Hach Lange spectrophotometer (Hach Lange, Salford Manchester, UK). The analysis, defined as Method 8196 in the DR 5000 user manual [23], was performed in triplicates for each sample, and the average of the three measurements was adopted as the VFA concentration for the sample.

\subsection{Data Analysis}

Regression analysis of recorded volatile solids concentrations during the BMP tests was conducted using non-linear least squares fit method to Equation 1 with the MATLAB curve fitting toolkit (MATLAB R2013a student version, Math Works, Cambridge, UK) [24]. Statistical analysis of the data fit to Equation 1 was carried out by the MATLAB curve fitting toolkit using the coefficient of determination $\left(R^{2}\right)$, the sum of squares due to errors (SSE) and root mean squared error (RMSE). $\mathrm{R}^{2}$ indicates the square of the correlation between the predicted model values to the initial observed values [25], while RMSE is the root-meansquare error, which is a measure of the differences between values predicted by the model and the values observed [26]. SSE is the sum of squares due to error, which measures the total deviation of the predicted values to the observed values. Data outliers, values outside 95\% confidence levels, were removed during the curve fitting process in order to get a fit between Equation 1 and the observed data.

Table 1: $350 \mathrm{~mL}$ BMP tests for domestic wastewater sludge

\begin{tabular}{cclcc}
\hline ID & $\begin{array}{c}\text { Temp. } \\
\left({ }^{\circ} \mathrm{C}\right)\end{array}$ & \multicolumn{1}{c}{ Substrate volume $(\mathrm{mL})$} & $\begin{array}{c}\text { Anaerobic biomass volume } \\
(\mathrm{mL})\end{array}$ & $\begin{array}{c}\text { Nutrient solution } \\
\text { volume }(\mathrm{mL})\end{array}$ \\
\hline $\mathrm{PS} 37^{\circ} \mathrm{C}$ & 37 & 150 Primary sludge & 100 Anaerobic biomass & 100 \\
$\mathrm{PS} 25^{\circ} \mathrm{C}$ & 25 & 150 Primary sludge & 100 Anaerobic biomass & 100 \\
$\mathrm{SS} 37^{\circ} \mathrm{C}$ & 37 & 150 Secondary sludge & 100 Anaerobic biomass & 100 \\
$\mathrm{SS} 25^{\circ} \mathrm{C}$ & 25 & 150 Secondary sludge & 100 Anaerobic biomass & 100 \\
Blank & 37 & - & 100 Anaerobic biomass & 250 \\
Blank & 25 & - & 100 Anaerobic biomass & 250 \\
\hline
\end{tabular}




\section{RESULTS AND DISCUSSION}

Initial characteristics of the sludge samples and anaerobic biomass in terms of total solids $(\mathrm{mg} / \mathrm{L})$, volatile solids $(\mathrm{mg} / \mathrm{L})$, volatile fatty acids $(\mathrm{mg} / \mathrm{L}$ acetic acid) and $\mathrm{pH}$ values are provided in Table 2 .

Table 2: Characteristics of solid substrates

\begin{tabular}{lccc}
\hline Parameter & $\begin{array}{c}\text { Primary } \\
\text { sludge }\end{array}$ & $\begin{array}{c}\text { Secondary } \\
\text { sludge }\end{array}$ & $\begin{array}{c}\text { Anaerobic } \\
\text { biomass }\end{array}$ \\
\hline Total solids (g/L) & 28.96 & 32.11 & 18.38 \\
$\begin{array}{l}\text { Volatile solids } \\
\text { (g/L) }\end{array}$ & 19.43 & 21.05 & 9.06 \\
$\begin{array}{l}\text { Volatile fatty acids } \\
(\mathrm{mg} / \mathrm{L})\end{array}$ & 359.30 & 240.10 & $\approx 0.00$ \\
$\mathrm{pH}$ & 5.98 & 6.22 & 7.70 \\
\hline
\end{tabular}

Note that " $\approx$ " in Table 2 indicates values observed were within margin of error of the analysis, and therefore considered as " 0.00 ", which is expected for the anaerobic biomass after degassing for 48 hours. The concentrations of solids in the primary sludge and secondary sludge indicates the sedimentation and dewatering processes in the wastewater treatment systems, instead of the quality of the initial wastewater before the treatment processes and collection of the sludge. After preparation of the BMP tests, the ratios of the mass of volatile solids in the substrates to the mass of volatile solids in the anaerobic biomass in the tests at initiation were 3.2:1 for the primary sludge tests and 3.5:1 for the secondary sludge tests. Figure 1 presents remaining fractions of volatile solids of the substrates against experimental time (days), and the results indicate that the reduction of the solid substrates for all the experimental conditions tested exhibited a trend similar to the model prediction, represented by the 'lines of best fit' in Figure 1.

Most of the reduction in solids was observed within the first ten days of the experiment, during which more than $30 \%$ of the primary sludge were reduced (Figure $1)$. The reduction of the solids for the secondary sludge was lower, about $20 \%$, than the reduction in the primary sludge. However, by the end of the experiment the reduction of primary sludge at $25^{\circ} \mathrm{C}$ was similar to the reduction of secondary sludge at $37^{\circ} \mathrm{C}$, about $40 \%$. The fractions of the substrates retained at the end of the experiment are indications of the inaccessible and non-biodegradable fractions of the substrates. The secondary sludge is expected to have smaller particle sizes than the primary sludge [27], therefore, the secondary sludge should be more accessible to the microorganisms during hydrolysis than the primary sludge. However, with the lower reduction of the solids in the secondary sludge compared to the primary sludge, there is a possibility that other factors, for example biomass to substrate ratio, influenced the hydrolysis of the sludge. From Equation 1, the remaining biodegradable fraction of the substrate depends on the hydrolysis rate and the digestion time, as defined in Equation 2.

$$
P_{\text {biodegradable }}=f_{h} P_{o} e^{-k_{h} t}
$$

In (2), $\mathrm{P}_{\text {biodegradable }}$ is the biodegradable concentration of total substrate $(\mathrm{mg} / \mathrm{L}), \mathrm{f}_{\mathrm{h}}$ is the biodegradable fraction of substrate, $\mathrm{k}_{\mathrm{h}}$ is the hydrolysis rate constant (day $\left.{ }^{-1}\right), \mathrm{t}$ is the time (day), and e is the 2.7182 .

The exponential component of the equation will increase with a decrease in the value of $k_{h} t$, therefore large $\mathrm{k}_{\mathrm{h}}$ values will yield low retention of biodegradable fractions compared to small $\mathrm{k}_{\mathrm{h}}$ values which should yield high retention of biodegradable fractions. A few data points presented in Figure 1 are higher than 1.0, and these values indicate experimental errors, potentially as a result of the sampling method adopted, where needles and syringes were used. Literature reviewed [19, 28 - 31] did not provide specific details of methods for collection of solid samples from closed batch test experiments such as the BMP tests. Researchers have proposed potential modifications to the methodology in order to avoid data errors [22], for example by monitoring the total mass of the system over time. Figure 2 presents the $\mathrm{pH}$ values in the tests for the corresponding experimental days, where all the $\mathrm{pH}$ values were within a range, 6.50 to 8.00 , suitable for anaerobic digestion without any substantial variation from this range, from the second day of the experiment.

During the experiment, the initial period was the hydrolysis and acid forming stage of the anaerobic digestion, and this is represented by the decrease in $\mathrm{pH}$ values in the first five days (Figure 2). The $\mathrm{pH}$ values did not fall below 5.0, which will have been an indication of process instability and accumulation of acids in the test [32], and the $\mathrm{pH}$ values stabilized without any $\mathrm{pH}$ adjustment during the experiment. Table 3 presents the summary of the reduction in terms of the fractions of the substrates removed by mass during the BMP test and the predicted reduction by mass using Equation 1, presented as the 'modelled' column.

In Table 3, "Temp" represent test temperatures, " $\mathrm{R}^{2}$ " represent the coefficients of determination, "SSE" represent the sums of squares due to errors and "RMSE" represent root mean squared errors of the BMP tests. The observed reduction of volatile solids of the 
substrates, Table 3, showed low reduction at $25^{\circ} \mathrm{Ccompared}$ to $37^{\circ} \mathrm{C}$, where for the primary sludge (PS) test, over $55 \%$ of the volatile solids were reduced at $37^{\circ} \mathrm{C}$, while only $40 \%$ reduction was observed at $25^{\circ} \mathrm{C}$ (Table 3 ). For the secondary sludge (SS) test, over $33 \%$ of the volatile solids were reduced at $37^{\circ} \mathrm{C}$, while only $22 \%$ reduction was observed at $25^{\circ} \mathrm{C}$. From Table 3 , the high $\mathrm{k}_{\mathrm{h}}$ values for the sludge correspond to the $25^{\circ} \mathrm{C}$ tests, while the low $\mathrm{k}_{\mathrm{h}}$ values correspond to the $37^{\circ} \mathrm{C}$ tests, however the retained biodegradable fractions were lower at $37^{\circ} \mathrm{C}$ than at $25^{\circ} \mathrm{C}$. This indicates that the rate of hydrolysis at $25^{\circ} \mathrm{C}$ was faster than at $37^{\circ} \mathrm{C}$, even though the degree of hydrolysis was substantially less at $25^{\circ} \mathrm{C}$ than at $37^{\circ} \mathrm{C}$. Furthermore, the degree of hydrolysis of the secondary sludge was substantially lower than the degree of hydrolysis of the primary sludge.

The correlation between the observed solids reduction and the prediction of Equation 1 can be evaluated based on the coefficient of determination $\left(\mathrm{R}^{2}\right)$ values obtained, which are indications of the usefulness of the model in predicting the process as a function of time [25]. This means if $\mathrm{R}^{2}$ is a value close to 1.0 , then Equation 1 is useful in predicting the hydrolysis of the substrate and the length of experimental time is important in determining the reduction in the substrate. While Equation 1 is not useful in predicting the hydrolysis of the substrate and the length of time is not important in determining the reduction in the substrate, if the $\mathrm{R}^{2}$ value is close to 0.0 .

Based on the $\mathrm{R}^{2}$ values obtained in Table 3 , Equation 1 is appropriate for use in the prediction of the reduction of primary and secondary sludge in batch systems with temperature and biomass conditions similar to the BMP tests in this study. From Table 3, the number of data points is an indication of the number of outlying data points (due to errors in measurements) that were not considered for the regression analysis.

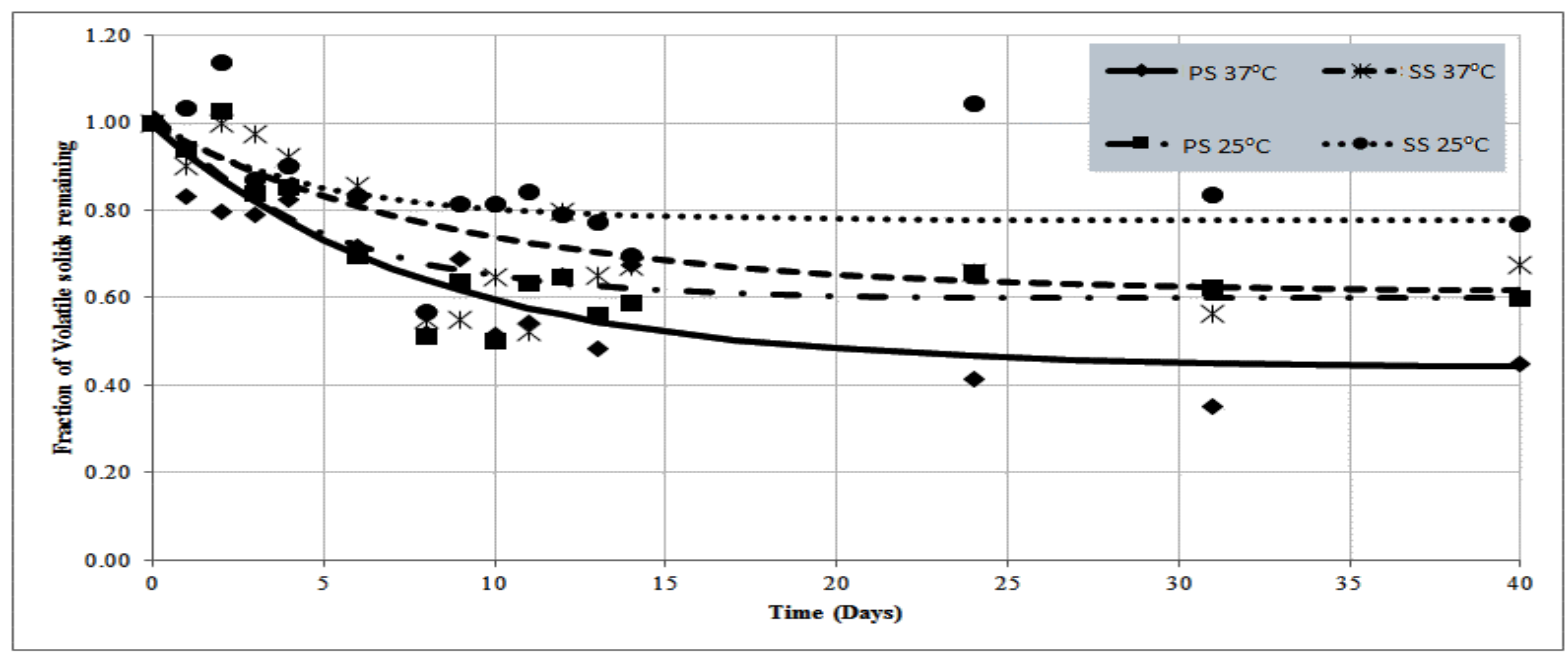

Figure 1: Retained solid substrates corresponding to length (days) of experiment.

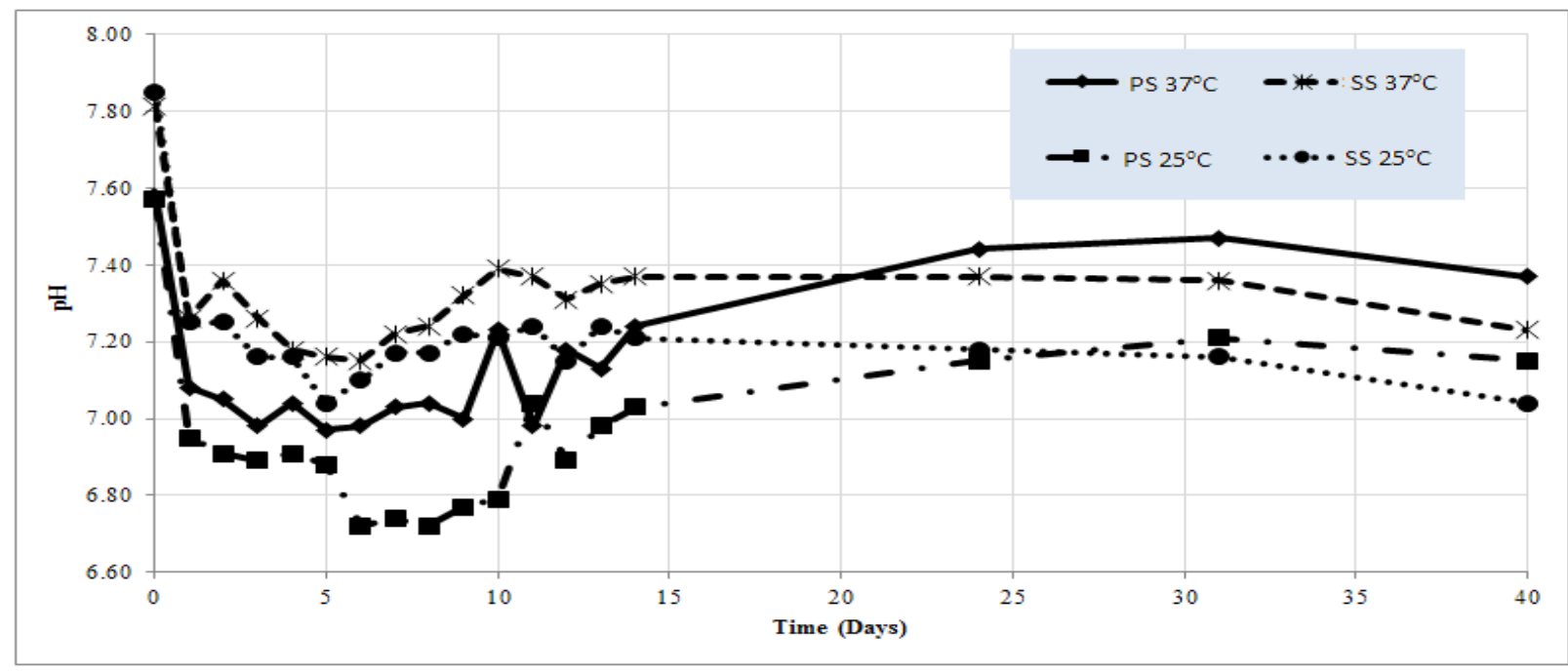

Figure 2: $p H$ values corresponding to length (days) of experiment. 
Table 3: Hydrolysis rate constants $\left(k_{h}\right)$ and statistical analysis

\begin{tabular}{|c|c|c|c|c|c|c|c|c|c|}
\hline Substrate & Temp. $\left({ }^{\circ} \mathrm{C}\right)$ & $\begin{array}{l}\text { Fraction } \\
\text { reduced } \\
\text { (observed) }\end{array}$ & $\begin{array}{l}\text { Fraction } \\
\text { reduced } \\
\text { (modelled) }\end{array}$ & Data points & $\mathrm{k}_{\mathrm{h}}\left(\mathrm{d}^{-1}\right)$ & $\begin{array}{l}\text { Bounds } \\
( \pm)\end{array}$ & $\mathrm{R}^{2}$ & RMSE & SSE \\
\hline \multirow{2}{*}{$\begin{array}{l}\text { Primary } \\
\text { sludge }\end{array}$} & 25 & 0.40 & 0.40 & 13 & 0.2089 & 0.0971 & 0.9325 & 0.0411 & 0.0169 \\
\hline & 37 & 0.55 & 0.56 & 13 & 0.1278 & 0.0964 & 0.8103 & 0.8100 & 0.0656 \\
\hline \multirow{2}{*}{$\begin{array}{l}\text { Secondary } \\
\text { sludge }\end{array}$} & 25 & 0.23 & 0.22 & 12 & 0.2194 & 0.2094 & 0.7490 & 0.0420 & 0.0158 \\
\hline & 37 & 0.33 & 0.38 & 11 & 0.1098 & 0.1036 & 0.8301 & 0.6570 & 0.0345 \\
\hline
\end{tabular}

Initially, there were 18 data points for the tests and at least three outlying points, data outside $95 \%$ confidence level, had to be removed (Table 3) before a data fit was achieved. The secondary sludge tests had at least 6 outlying data points removed before a fit to the model was observed, but primary sludge tests had no more than five data points removed. These observed outlying data points are probably due to errors as a result of the sampling process, and the statistical error analysis (RSME and SSE in Table 3) provides additional details on the distribution of the observed data points relative to the model with respect to time [26].

The highest RSME value in Table 3 was for the primary sludge test at $37^{\circ} \mathrm{C}$, observed with RSME $=0.8100$, and also for the secondary sludge test at $37^{\circ} \mathrm{C}$, observed with RSME $=0.6570$. The differences between the predicted model values and the observed values for the other tests were small, as reflected by the small RSME values (Table 3), indicating that most of the observed values are close to the predicted model values. The SSE values provide another basis for comparison of the deviation of the predicted values from the observed values, and low SSE values in Table 3 indicate that the model, based on the hydrolysis rate and time, is predicting values that are close to the observed values. The hydrolysis rates constants $\left(\mathrm{k}_{\mathrm{h}}\right)$ obtained (Table 3 ), are within the range of values observed in literature for primary sludge and secondary sludge, and summarized in Table 4.

Aldin [16] reported hydrolysis rate constants $\left(\mathrm{k}_{\mathrm{h}}\right)$ for wastewater sludge within the range of 0.0096 to 1.94 day $^{-1}$ for primary sludge, 0.005 to 0.2 day $^{-1}$ for sewage sludge, with 0.08 to 2.0 day $^{-1}$ as the general range for most types of sludge. Eastman and Ferguson [35], Batstone et al. [36] and Siegrist et al. [37], reported hydrolysis rate constants for primary sludge between 0.2 - 0.5 day $^{-1}$ at mesophilic conditions, while Mahmoud [34] reported $0.23 \mathrm{day}^{-1}$ for settle-able solids from domestic wastewater at $35^{\circ} \mathrm{C}$. Kassab et al. [33] reported hydrolysis rate constants based on first order kinetics as 0.006 day $^{-1}$ for seeded domestic wastewater sludge, and 0.004 day $^{-1}$ for unseeded domestic wastewater sludge.

From Table 4, the $\mathrm{k}_{\mathrm{h}}$ values reported by Aldin [16] were for a wide range of experiments, while Kassab et al. [33] reported the potential influence of high concentrations of detergents in their substrate as the reason for the low rate constants. Nielsen [38], Lee Ferguson and Brown well [39] and Jimenez-Gonzalez et al. [40], have reported poor anaerobic degradation due to detergents, mainly as a result of process inhibition [41-42]. Even though the $\mathrm{k}_{\mathrm{h}}$ values from this study are close to the values reported by Mahmoud [34] and Luo et al. [15], and the values also fall within the ranges reported by Aldin [16], there is need for caution in comparison of the values due to the different experimental conditions. The summary presented in Table 4 indicates wide ranges of values for the hydrolysis rates, and this could be attributed to the differences in the nature and characteristics of the substrates and the experimental conditions. However, the correlation of the first order hydrolysis model, after discarding of data outliers, provides a basis for comparison of hydrolysis experiments with different substrates.

\section{CONCLUSION}

The potential for anaerobic reduction of domestic wastewater sludge at $25^{\circ} \mathrm{C}$ was evaluated and compared against anaerobic reduction at $37^{\circ} \mathrm{C}$, and generally the secondary sludge (SS) showed lower reduction than the primary sludge. The results also revealed higher reduction at $37^{\circ} \mathrm{C}$ than at $25^{\circ} \mathrm{C}$ for the primary sludgetests, where over $55 \%$ of the volatile solids were reduced at $37^{\circ} \mathrm{C}$, while only $40 \%$ reduction was observed at $25^{\circ} \mathrm{C}$. For the secondary sludge (SS) test, over $33 \%$ of the volatile solids were reduced at $37^{\circ} \mathrm{C}$, while only $22 \%$ reduction was observed at $25^{\circ} \mathrm{C}$. 
Table 4: Summary of $k_{h}$ values from literature and this study

\begin{tabular}{llll}
\hline Study & Substrate & kh (day-1) & Conditions \\
\hline Aldin[16] & Sewage sludge & $0.0050-0.2000$ & Varying \\
Aldin[16] & Sludge & $0.0800-2.0000$ & Varying \\
Aldin[16] & Primary sludge - lipids and proteins & $0.0096-0.1700$ & Varying \\
Aldin[16] & Primary sludge - carbohydrates & $0.2100-1.9400$ & Varying \\
Kassab et al. [33] & Domestic wastewater - sludge & 0.0060 & $25^{\circ} \mathrm{C}$ - seeded \\
Kassab et al. [33] & Domestic wastewater - sludge & 0.0040 & $25^{\circ} \mathrm{C}$ - unseeded \\
Mahmoud [34] & Domestic wastewater - Settle-able solids & 0.2300 & $35^{\circ} \mathrm{C}$ \\
This study & Primary sludge - volatile solids & $0.2089 \pm 0.0971$ & $25^{\circ} \mathrm{C}$ - seeded \\
This study & Primary sludge - volatile solids & $0.1278 \pm 0.0964$ & $37^{\circ} \mathrm{C}$ - seeded \\
This study & Secondary sludge - volatile solids & $0.2194 \pm 0.2094$ & $25^{\circ} \mathrm{C}$ - seeded \\
This study & Secondary sludge - volatile solids & $0.1098 \pm 0.1036$ & $37^{\circ} \mathrm{C}$ - seeded \\
\hline
\end{tabular}

The rates of hydrolysis observed were higher at $25^{\circ} \mathrm{C}$ than at $37^{\circ} \mathrm{C}$, while lower degrees of hydrolysis at $25^{\circ} \mathrm{C}$ than at $37^{\circ} \mathrm{C}$ were observed. $\mathrm{R}^{2}$ values calculated based on the data from the reduction of the domestic wastewater sludge, indicated a good correlation of the hydrolysis model, digestion time and the reduction of the solids. Errors in the data indicated by data outliers, potentially due to the sample collection method adopted, constrained the curve fitting process and resulted in the discarding of data points, especially for the secondary sludge. Research into modification of the methodology, specifically the development of a reliable method to monitor the reduction of solids, may enhance the reliability of data collection, and lead to improvements in the hydrolysis process.

\section{ACKNOWLEDGEMENT}

The authors gratefully acknowledge the financial support of the Petroleum Technology Development Fund (PTDF) of Nigeria and Ahmadu Bello University, Zaria, Nigeria in sponsoring the $\mathrm{PhD}$ research degree that yielded this paper. The authors also acknowledge the support of the staff of Abertay University, Dundee, United Kingdom, where the experiment was carried out. The authors also gratefully acknowledge the contributions of Professor Joe Akunna of Abertay University for his support and guidance during the period of the research, and also the technical contributions of Mr. T Feuvrier in the conduct of the batch experiments.

\section{REFERENCES}

[1] Mara, D. Domestic wastewater treatment in developing countries, Earthscan, London, 2003.
[2] Davis, M. L. Water and wastewater engineering design principles and practice, McGraw-Hill Company, New York, 2011.

[3] Verstraete, W., Van de Caveye, P. and Diamantis, V. Maximum use of resources present in domestic used water. Bioresource Technology, Volume 100, Number 23, pp. 5537 - 5545, 2009.

[4] Nielfa, A., Cano, R. and Fdz. Polanco, M. "Theoretical methane production generated by the co-digestion of organic fraction municipal solid waste and biological sludge", Biotechnology Reports, Volume5, pp. 14 -21, 2015.

[5] Gomec, C. Y. "High-rate anaerobic treatment of domestic wastewater at ambient operating temperatures: a review on benefits and drawbacks", Journal of Environmental Science and Health Part A, Volume 45, Number 10,pp.1169 1184, 2010.

[6] Mrowiec, B. and Suschka, J. Anaerobic wastewater treatment processes. University of Bielsko-Biala, Poland. Available online at: http://www2.lwr.kth.se/forskningsprojekt/Polis hproject/rep16/MrowiecSuschka.pdf. Accessed on November 27, 2015.

[7] Bergamo, C. M., Monaco R. D., Ratusznei S. M., Rodrigues J. A. D., Zaiat M. and Foresti E. "Effects of temperature at different organic loading levels on the performance of a fluidized-bed anaerobic sequencing batch bioreactor", Chemical Engineering and Processing: Process Intensification, Volume 48, Number 3, ,pp.789 796, 2009.

[8] Lettinga G., Rebac, S. and Zeeman, G. "Challenge of psychrophilic anaerobic wastewater treatment", Trends in Biotechnology, Volume 19, Number 9,), pp.363 - 370, 2001.

Vol. 36, No. 4, October 2017, 
[9] Griffin, L. P. Anaerobic digestion of organic wastes: the impact of operating conditions on hydrolysis efficiency and microbial community composition. [Master's thesis]. Colorado State University, USA. Available online at: http://erefdn.org/images/uploads/Griffin_Laura. pdf. Accessed on November 27, 2015.

[10] Vavilin, V. A., Fernandez, B., Palatsi, J. and Flotats, $\mathrm{X}$. "Hydrolysis kinetics in anaerobic degradation of particulate organic material: an overview", Waste Management, Volume 28, Number6, pp.939 - 951, 2008.

[11] Weichgrebe S. A. D. and Rosenwinkel K. H. Determination of the hydrolysis constant using Anaerobic Batch Tests. Paper presented at: $13^{\text {th }}$ IWA world congress on anaerobic digestion. Santiago de Compostela, Spain. June 25-28, 2013.

[12] Appels, L., Baeyens, J., Degrève, J., and Dewil, R. Principles and potential of the anaerobic digestion of waste-activated sludge. Progress in Energy and Combustion Science. Volume 34, Number 6, pp. 755 - 781, 2008.

[13] Mottet, A., François, E., Latrille, E., Steyer, J. P., Déléris, S., Vedrenne, F., and Carrère, H. Estimating anaerobic biodegradability indicators for waste activated sludge. Chemical engineering journal. Volume 160, Number 2, pp. 488 - 496, 2010.

[14] Feng, L., Yan Y., and Chen Y. Kinetic analysis of waste activated sludge hydrolysis and short-chain fatty acids production at $\mathrm{pH} 10$. Journal of Environmental Sciences. Volume 21, Number 5, pp. 589 - 594, 2009.

[15] Luo, K., Yang, Q., Li, X., Yang, G., Liu, Y., Wang, D., Zheng, W. and Zeng, G. "Hydrolysis kinetics in anaerobic digestion of waste activated sludge enhanced by $\alpha$-amylase", Biochemical Engineering Journal, Volume 62, pp.17 - 21, 2012.

[16] Aldin, S. The effect of particle size on hydrolysis and modelling of anaerobic digestion. [PhD dissertation]. University of Western Ontario, Ontario, Canada. Available from: http://ir.lib.uwo.ca/cgi/viewcontent.cgi?article= $1167 \&$ context $=$ etd. Accessed on November 27, 2015.

[17] Vavilin, V. A., Rytov, S. V., and Lokshina, L. Y. “A description of hydrolysis kinetics in anaerobic degradation of particulate organic matter",
Bioresource Technology, Volume 56, Number 2, pp.229 - 237,1996.

[18] Angelidaki, I. and Sanders, W. "Assessment of the anaerobic biodegradability of macropollutants", Reviews in Environmental Science and Biotechnology, Volume 3, Number 2, pp.117 - 129, 2004.

[19] Angelidaki, I., Alves, M., Bolzonella, D., Borzacconi, L., Campos, L., Guwy, A., and van Lier, J. B. "Defining the bio-methane potential (BMP) of solid organic wastes and energy crops: a proposed protocol for batch assays", Water Science and Technology, Volume 59, Number 5, pp.927 - 934, 2009.

[20] American Public Health Association. Standard methods for the examination of water and wastewater, $20^{\text {th }}$ edition,American Public Health Association (APHA) - American Water Works Association (AWWA) - Water Environment Federation (WEF), Washington, DC., 1998.

[21] Hierholtzer, A., Chatellard, L., Kierans, M., Akunna, J. C., and Collier, P. J. "The impact and mode of action of phenolic compounds extracted from brown seaweed on mixed anaerobic microbial cultures", Journal of Applied Microbiology, Volume 114, Number4, pp.964 973, 2013.

[22] Abubakar, U. A. A technological model for low energy domestic wastewater treatment. [PhD dissertation]. November, 2015. Abertay University, Dundee, United Kingdom. Available online

at:

https://repository.abertay.ac.uk/jspui/handle/10 $\underline{373 / 2615}$.

[23] Hach Company. DR5000 Spectrophotometer procedures manual, Catalog number DOC082.98.00670. $2^{\text {nd }}$ edition, Germany, 2005.

[24] MATLAB and Curve fitting toolkit Release a student version, MathWorks, Cambridge, UK, 2013.

[25] Palmer, P. B., and O'Connell, D. G. "Regression analysis for prediction: understanding the process", Cardiopulmonary Physical Therapy Journal, Volume 20, Number 3, pp.23-26, 2009.

[26] Willmott, C. J., Ackleson, S. G., Davis, R. E., Feddema, J. J., Klink, K. M., Legates, D. R., and Rowe, C. M. "Statistics for the evaluation and 
comparison of models", Journal of Geophysical Research, Volume 90, 1985, pp.8995 - 9005

[27] Morgenroth, E., Kommedal, R. and Harremos, P. Processes and modelling of hydrolysis of particulate organic matter in aerobic wastewater treatment-a review. Water Science and Technology. Volume 45, Number 6, pp.25 - 40. 2002.

[28] Raposo, F., De la Rubia, M. A., Fernández-Cegrí, V., and Borja, R. "Anaerobic digestion of solid organic substrates in batch mode: an overview relating to methane yields and experimental procedures", Renewable and Sustainable Energy Reviews, Volume 16, Number 1, pp.861 877,2011.

[29] de Vrieze, J., Raport, L., Willems, B., Verbrugge, S., Volcke, E., Meers, E, and Boon, N. "Inoculum selection influences the biochemical methane potential of agro-industrial substrates", Microbial Biotechnology, Volume 8, Number 5, pp. 776-786, 2015.

[30] Hansen, T. L., Schmidt, J. E., Angelidaki, I., Marca, E., la Cour Jansen, J., Mosbæk, H., and Christensen, T. H. "Method for determination of methane potentials of solid organic waste", Waste Management, Volume 24, Number 4, pp.393 400,2004 .

[31] Owen, W. F., Stuckey, D. C., Healy, J. B., Young, L. Y., and McCarty, P. L. "Bioassay for monitoring biochemical methane potential and anaerobic toxicity", Water Research, Volume 13, Number 6, pp.485 - 492,1979.

[32] Langenhoff, A. A. and Stuckey, D. C. Treatment of dilute wastewater using an anaerobic baffled reactor: effect of low temperature. Water Research. Volume 34, Number 15, , pp.3867 3875, 2000.

[33] Kassab, G., Halalsheh, M., Abu-Ghunmi, L. and Shatanawi, K. "Characterization and anaerobic biodegradation of single house wastewater", Jordan Journal of Civil Engineering, Volume 7, Number 2, pp.202 - 210, 2013.

[34] Mahmoud, N. Anaerobic pre-treatment of sewage under low temperature $\left(15^{\circ} \mathrm{C}\right)$ conditions in an integrated UASB-digester system. $[\mathrm{PhD}$ dissertation]. Wageningen University,
Wageningen, the Netherlands. Available online at: http://www.ircwash.org/resources/anaerobicpre-treatment-sewage-under-low-temperature15-c-conditions-integrated-uasb. Accessed on November 27, 2015.

[35] Eastman, J. A. and Ferguson, J. F. "Solubilization of particulate organic carbon during the acid phase of anaerobic digestion", Journal Water Pollution Control Federation, Volume 53, Number 3, pp.352 - 366, 1981.

[36] Batstone, D. J., Keller, J., Angelidaki, I., Kalyuzhnyi, S. V., Pavlostathis, S. G., Rozzi, A., Sanders, W. T. M., Siegrist, H. and Vavilin, V. A. "Anaerobic Digestion Model No1 (ADM1)", Water Science and Technology, Volume 45, Number 10, pp.65 - 73, 2002.

[37] Siegrist, H., Vogt, D., Garcia-Heras, J. L. and Gujer, W. "Mathematical model for meso-and thermophilic anaerobic sewage sludge digestion", Environmental Science and Technology, Volume 36, Number 5, pp.1113 - 1123, 2002.

[38] Nielsen, S. "Mineralisation of hazardous organic compounds in a sludge reed bed and sludge storage", Water Science and Technology, Volume 51, Number9, pp.109-117, 2005,

[39] Lee Ferguson, P. and Brownawell, B. J. "Degradation of nonylphenolethoxylates in estuarine sediment under aerobic and anaerobic conditions", Environmental Toxicology and Chemistry, Volume 22, Number 6, pp.1189 - 1199, 2003.

[40] Jimenez-Gonzalez, A., Salazar-Gonzlez, M., Gutirrez-Rojas, M., and Monroy, O. "Anaerobic digestion of a nonionic surfactant: inhibition effect and biodegradation", Water Science and Technology, Volume 44, Number 4, 175-181, 2001.

[41] Mensah, K. A. and Forster, C. F. "An examination of the effects of detergents on anaerobic digestion", Bioresource Technology, Volume 90, Number 2, pp.133 - 138, 2003.

[42] Hernández-Leal, L., Temmink, H., Zeeman, G. and Buisman, C. J. N. "Characterization and anaerobic biodegradability of grey water", Desalination, Volume 270, Number 1, pp.111 - 115, 2011. 